\title{
Deforestation of the Atlantic Forest in the state of Ceará: analysis of the Environmental Kuznets Curve from panel data, 2011 to 2017
}

\author{
Desmatamento da Mata Atlântica no estado do Ceará: análises da Curva de \\ Kuznets Ambiental a partir de dados em painel, 2011 a 2017

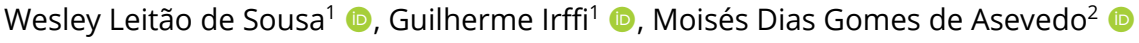 \\ 'Programa de Pós-graduação em Economia, Universidade Federal do Ceará (UFC), Fortaleza (CE), Brasil. E-mails: \\ wesleyleitao@alu.ufc.br; irffi@caen.ufc.br \\ ${ }^{2}$ Universidade Federal do Ceará (UFC), Fortaleza (CE), Brasil. E-mail: moisesdga@gmail.com
}

\begin{abstract}
How to cite: Sousa, W. L., Irffi, G., \& Asevedo, M. D. G. (2022). Deforestation of the Atlantic Forest in the state of Ceará: analysis of the Environmental Kuznets curve from panel data, 2011 to 2017. Revista de Economia e Sociologia Rural, 60(1), e229884. https://doi.org/10.1590/1806-9479.2021.229884
\end{abstract}

\begin{abstract}
This research aims to analyze the relationship between the deforestation of the Atlantic Forest and economic activity, under the hypothesis of the Environmental Kuznets Curve, considering the municipalities of the state of Ceará. For this, it is estimated a Tobit model for panel data, in the period from 2011 until 2017, considering the GDP per capita and controlling for associated factors with both deforestation and environmental protection. Unlike the expectations, the population density and cattle farming soften deforestation activity. The evidence found for the relationship between deforestation and GDP per capita rejects the "Inverted- $U$ " hypothesis, and yes, suggests the " $\mathrm{N}$ " format, indicating that deforestation in the region may be cyclical. Therefore, there are no indications to ensure that the economic activity of the municipalities analyzed assure by itself the environmental protection and sustainable use of the Atlantic Forest and associated ecosystems in the state of Ceará.
\end{abstract}

Keywords: Ceará, Environmental Kuznets Curve, deforestation, Atlantic Forest.

Resumo: Esta pesquisa tem por objetivo analisar a relação entre desmatamento da Mata Atlântica e atividade econômica, sob a hipótese da Curva de Kuznets Ambiental, considerando os municípios do estado do Ceará. Para isto, estima-se um modelo tobit para dados em painel, no período de 2011 a 2017, considerando o PIB per capita e controlando por fatores associados tanto ao desmatamento quanto à proteção ambiental. Ao contrário do esperado, a densidade populacional e a bovinocultura suavizam a atividade do desmatamento. As evidências encontradas para a relação entre desmatamento e PIB per capita rejeitam a hipótese de "U-invertido" e, sim, sugerem o formato de "N", indicando que o desmatamento na região pode ser cíclico. Desta forma, não existem indicativos para assegurar que a atividade econômica dos municípios analisados garanta por si só a proteção ambiental e o uso sustentável da Mata Atlântica e ecossistemas associados no estado do Ceará.

Palavras-chave: Ceará, Curva de Kuznets Ambiental, desmatamento, Mata Atlântica.

\section{Introduction}

The degradation of forest ecosystems is due to several factors, especially activities of anthropic origin. In this sense, there is a substantial concern that, as the economic development advances, the environmental pressure on ecosystems exceeds the capacity supported by the environment itself. The relationship between economic development and environmental degradation is found in the Environmental Kuznets Curve (EKC), initially proposed by Grossman \& Krueger (1995). 
EKC's premise assumes that, at low levels of development, the growth of income per capita $(p c)$ induces an increase in environmental degradation. However, after a certain level of income, this logic would reverse, with an increase in income $p c$ leading to a reduction in environmental degradation, characterizing a curve in the shape of an "Inverted-U". Thus, Grossman \& Krueger (1995) related income $p c$ to water and air quality indicators and found evidence for several developed countries, that environmental degradation increases with economic growth to an inflection point from which there is an improvement in environmental quality resulting in the EKC.

In Brazil, several studies elaborate on the relationship between economic development and indicators of environmental degradation. Hence, one of the most pertinent ecological guidelines, concerns deforestation in national biomes, focusing on regions such as the Amazon and Cerrado (e.g. Colusso et al., 2012; Oliveira et al., 2011) especially due to their territorial extension ecosystems, the expansion of the agricultural frontier in these places and the availability of information. On the other hand, there is a gap in the research that links economic development and changes in forests in other national biomes (i.e. Caatinga, Atlantic Forest, Pampa, and Pantanal).

Regarding the Atlantic Forest and natural non-forest areas ${ }^{1}$, their limits currently occupy $12.4 \%$ of the country, distributed in 17 states. According to the "Atlas of the Remnants of the Atlantic Forest", from 1985 to 2019, the anthropic action deforested around 1.95 million acres of this forest coverage. Deforestation between 2018 to 2019 was 14,502 acres, 27.2\% higher than the period between 2017 and 2018. Of the 17 states monitored between 2018 and 2019, nine registered zero deforestation ( $<100$ acres), namely: Alagoas (AL), Ceará (CE), Espírito Santo (ES), Goiás (GO), Paraíba (PB), Pernambuco (PE), Rio de Janeiro (RJ), Rio Grande do Norte (RN), and São Paulo (SP) (SOS Atlantic Forest Foundation \& National Institute for Space Research [INPE], 2020a).

Among these regions, the state of Ceará stands out, with remnants of the Atlantic Forest and non-forest natural areas occupying 64,064 and 125,519 acres, respectively, or $1.3 \%$ of the state. In the region, 61 municipalities have remnants of native forest, and therefore, by observing the deforestation data, it can be noticed that, since 2014, the state has recorded zero deforestation ( $<100$ acres) of Atlantic Forest, with a subsequently $40 \%$ increase in deforestation in the periods 2017 to 2018 and 2018 to 2019. Concerning non-forest areas, in the period from 2018 to 2019 alone, 804 acres of herbaceous restinga were deforested (Fundação SOS Mata Atlântica, 2020a).

In light of the abovementioned situation, this paper aims to analyze the relationship between environmental degradation and economic activity, as proposed by the EKC hypothesis, in the 61 municipalities of Ceará that have remnants of the Atlantic Forest and associated ecosystems, considering the deforestation indicator. Therefore, the goal is to investigate if there is an "Inverted-U" relationship between GDPpc and the annual deforested area, obtained after the "Aqui tem Mata?" Project data, for the period between 2011 and 2017, using a panel data model. In addition to the variable related to economic activity, there are control variables associated with: agriculture, consumption, demography, economic and tax information, the labor market, and geoenvironmental aspects were added.

Although several surveys estimate an EKC for Brazil based on several sustainable development indicators, none of them used the deforestation of the Atlantic Forest and nonforest natural areas as a proxy for environmental degradation. Also, EKC's empirical analyzes focus on states and municipalities that have limits on the Amazon and the Cerrado. Hence, the literature does not present evidence for the state of Ceará, regarding the Caatinga and Atlantic Forest domains. Therefore, this research contributes to the EKC literature for the Atlantic Forest biome.

To achieve the proposed objectives, this article is divided into five sections, including this introduction. The next one is dedicated to exposing the empirical literature on EKC, focusing on deforestation. The source and description of the data, as well as the empirical model, are

\footnotetext{
${ }^{1}$ Lowlands, natural altitude fields, vegetation refuges, dunes, herbaceous restinga, apicum, wetland and humid field.
} 
presented in the third section. Subsequently, the results are exposed, discussed, and analyzed. Finally, the conclusions are presented.

\section{Literature Review}

\subsection{Empirical literature on EKC focused on deforestation}

To conduct this literature review, we decided to apply the descriptors "Environmental Kuznets Curve" + "Deforestation" on Google Scholar's database. The criteria for the inclusion of the available articles were: publications in national or international journals, in English, Portuguese or Spanish, with publication date starting in 2010, selection of updated references, and preference for studies carried out in Brazilian biomes. Based on these selection procedures, the content of this article is evaluated considering the study area, period, methodology, and results.

Oliveira et al. (2011) investigated deforestation under the hypothesis of EKC in the municipalities of the Amazônia Legal from 2001 to 2006. To do so, they controlled for indicators related to agriculture, demography, economics, forestry, and mineral extraction. They found an "N-inverted" format for the EKC, hence, deforestation decreases at low levels of income $p c$, experiences a period of increase, and decreases again when a high level of income $p c$ is reached.

Ferreira \& Coelho (2015) explored how the prices of agricultural commodities, public inspection policies, and rural credit, have affected deforestation in the Amazônia Legal region from 1999 to 2011. The results obtained suggest that commodities prices and rural credit policies increase deforestation, while inspection policies have helped to mitigate deforestation.

Regarding the discussion between deforestation and regional development, Teixeira, Bertella \& Almeida (2012) investigated the relationship between deforestation levels and income growth for 139 municipalities in the state of Mato Grosso (MT). Using data from 2006, an EKC was estimated for deforestation $p c$ in relation to income $p c$ and its quadratic term, in addition to: cattle over pasture area, demographic density, wood extraction pc, and spatial effects. The results found led to the inference that the EKC follows an "Inverted-U" format, but when using a cubic term for income, economic growth would not be linked to the deforestation of the municipalities of Mato Grosso.

Colusso et al. (2012) discuss the relationship between environmental degradation and economic activity, from the perspective of EKC, in the Brazilian Cerrado, for the year 2008. The dependent variable is set as the deforested area of Cerrado in the municipalities of the biome and, as explanatory variables, there are: GDPpc and its quadratic and cubic shapes, population density, planted area, and cattle herd. The tested hypothesis resulted that, in the first stage, the growth of income $p c$ contributes to the reduction of deforestation in the region; however, the continuous increase in income causes deforestation to increase again.

For MATOPIBA², Barros \& Stege (2019) investigated the existence of an EKC of the relationship between deforestation and the Human Development Index (HDI) in the 337 municipalities of the region in 2010. The Exploratory Analysis of Spatial Data (AEDE) combined with Spatial econometrics corroborated the "Inverted-U" format of the EKC. The turning point, at which development reaches its maximum, is at an $\mathrm{HDI}$ of 0.57 , with $28.18 \%$ of the municipalities being below this value. In addition, controls related to the advance of the agricultural frontier induce deforestation in the region.

Although the aforementioned articles directly address deforestation and its relationship to economic growth, there are others that, even though do not address the subject directly, explain the issuance of greenhouse gases as a consequence of deforestation and which in

${ }^{2}$ Current Brazilian agricultural frontier, the MATOPIBA covers the Cerrado biome of the states of Maranhão, Tocantins, Piauí and Bahia, and accounts for a large part of the national production of grains and fibers (Empresa Brasileira de Agropecuária, 2020). 
turn are affected by economic growth ${ }^{3}$ (i.e. Almeida \& Lobato, 2019; Biage \& Almeida, 2015; Carvalho \& Almeida, 2010).

Carvalho \& Almeida (2010) tested the EKC hypothesis in a sample of 187 countries for 2004. The dependent variable is set as $\mathrm{CO}_{2}$ emissions and as independent variables, there are: GDPpc and its quadratic and cubic forms, exports pc, consumption pc energy, and a dummy indicating the signatory countries to the Kyoto Protocol. The results corroborate the "Inverted- U" format, thus, economic growth reduces the environmental impact of emissions. The addition of the cubic term, however, results in an " $\mathrm{N}$ " shape curve, demonstrating that high levels of growth can increase $\mathrm{CO}_{2}$ emissions. Moreover, Kyoto Protocol signatory countries have significantly reduced pollutant emissions.

Biage \& Almeida (2015) evaluated the EKC hypothesis applied to a panel data format, analyzing the differences between $\mathrm{CO}_{2}$ emissions by countries, depending on socio-economic development. As a result, a relationship between GDPpc and the $\mathrm{CO}_{2} \mathrm{pc}$ emission with the EKC in an " $\mathrm{N}$ " format became evident. In addition, the results showed that GDPpC is the variable with the least impact on $\mathrm{CO}_{2}$ emissions and that the environmental impact grows, essentially, due to the development of economies (economic development, social development, and quality of life).

Almeida \& Lobato (2019) approach the EKC discussion for the Northern region of Brazil from 2002 to 2015. The authors linked $\mathrm{CO}_{2}$ emissions to GDPpC, and although they do not directly address deforestation, they took into account that the $\mathrm{CO}_{2}$ emissions are a consequence of factors such as deforestation itself, being treated as a proxy variable. The research concluded that the EKC for the northern region of Brazil has a " $U$ " shape, not corroborating the traditional EKC format.

Relevant studies for the development of this paper refer to the evaluation of deforestation, without the need to test the EKC hypothesis. Their importance relates to the evaluation of the determinants of deforestation in Brazilian biomes, or the development of environmental impact indicators, in order to identify causes of environmental degradation.

From another perspective, Delazeri (2016) listed the causes of deforestation in the Arco Verde communities in the Amazônia Legal between 2008 and 2012. The result led to conclude that cattle production has a greater incidence in the levels of deforestation in the 49 municipalities that make up the region and that the expansion of soybean crops is not significant to explain deforestation.

In an investigation into the occurrence of environmental impact decoupling from Brazilian economic growth, Soares \& Almeida (2018) grouped 13 environmental pressure indicators, monitored from the 1990 s to mid-2014, in the dimensions ${ }^{4}$ : water, atmosphere, biodiversity, sanitation, and land. The research corroborated the hypothesis that economic growth causes environmental impact, including on the biodiversity that comprehends the Atlantic Forest, but with less impact on the land dimension.

Castelo, Adami, Almeida \& Almeida (2018) evaluated environmental public policies of the federal government in the fight against deforestation in the Amazon, from a historical survey of the activity for a period of 15 years (2002 to 2016). The empirical analysis carried out for the state of Pará using a panel modeling showed that, given the increase of 100 bovine heads, the deforested area has increased by $0.2 \mathrm{~km}^{2}$, since the environmental policy was quite significant for the period analyzed.

Briefly, Table 1 summarizes the studies that assess the relationship between economic growth and deforestation in Brazilian biomes under the hypothesis of EKC. In general, these

\footnotetext{
3 Almeida \& Lobato (2019), Biage \& Almeida (2015) corroborate that the increase in economic activity increases deforestation via the agricultural sector with: burning in agriculture, extraction of forest resources, and pasture areas, which reduce $\mathrm{CO}_{2}$ absorption, increasing $\mathrm{GHG}$ emissions.

${ }^{4}$ Water: biochemical oxygen demand (1990 to 2014), beach water quality (1992 to 2012). Atmosphere: anthropogenic GHG emissions (1990 to 2014), industrial consumption of ozone-depleting substances (1992 to 2013). Biodiversity (1992 to 2013): protected land areas, marine protection areas. Sanitation (1992 to 2011): access of the population to drinking water, sewerage and to the domestic garbage collection service. Land: deforestation of the Amazônia Legal (1990 to 2014), use of fertilizer (1992 to 2013), land use (1990 to 2011).
} 
empirical studies consider econometric approaches for cross-sectional data or in panel data format. In addition, much of the national research is concentrated in the Midwest, North, and MATOPIBA municipalities. Thus, through this review, it can be said that the present research contributes to the EKC literature based on the analysis of the relationship between economic activity in the state of Ceará and the deforestation of the forest remnants of the Atlantic Forest and non-forest natural areas.

Table 1. Summary of the works considered by EKC and/or Deforestation.

\begin{tabular}{|c|c|c|c|c|c|}
\hline Authors & Period & Method & Region & EKC & Deforestation \\
\hline \multicolumn{6}{|c|}{ Cross-Section } \\
\hline Barros \& Stege (2019) & 2010 & & $\begin{array}{l}337 \text { municipalities } \\
\text { of MATOPIBA }\end{array}$ & $\sqrt{ }$ & $\sqrt{ }$ \\
\hline $\begin{array}{l}\text { Carvalho \& Almeida } \\
\qquad(2010)\end{array}$ & 2010 & & 187 countries & $\sqrt{ }$ & - \\
\hline Colusso et al. (2012) & 2008 & $\begin{array}{c}\text { Spatial } \\
\text { Econometrics }\end{array}$ & $\begin{array}{c}1.306 \\
\text { municipalities } \\
\text { with Cerrado area } \\
\text { in Brazil }\end{array}$ & $\sqrt{ }$ & $\sqrt{ }$ \\
\hline Teixeira et al. (2012) & 2006 & & $\begin{array}{l}\text { Mato Grosso } \\
\text { municipalities }\end{array}$ & $\sqrt{ }$ & $\sqrt{ }$ \\
\hline \multicolumn{6}{|c|}{ Panel Data } \\
\hline $\begin{array}{l}\text { Almeida \& Lobato } \\
\text { (2019) }\end{array}$ & 2002 to 2015 & & $\begin{array}{l}\text { States in the } \\
\text { North Region }\end{array}$ & $\sqrt{ }$ & - \\
\hline $\begin{array}{l}\text { Biage \& Almeida } \\
\qquad(2015)\end{array}$ & 1991 to 2006 & & 37 countries & $\sqrt{ }$ & - \\
\hline Castelo et al. (2018) & 2002 to 2016 & Fixed Effects & $\begin{array}{c}\text { Municipalities of } \\
\text { Pará }\end{array}$ & - & $\sqrt{ }$ \\
\hline Delazeri (2016) & 2008 to 2012 & & $\begin{array}{c}\text { Arco Verde } \\
\text { (Amazônia Legal) }\end{array}$ & - & $\sqrt{ }$ \\
\hline $\begin{array}{l}\text { Ferreira \& Coelho } \\
\qquad(2015)\end{array}$ & 1999 to 2011 & & $\begin{array}{c}\text { States of } \\
\text { Amazônia Legal }\end{array}$ & $\sqrt{ }$ & $\sqrt{ }$ \\
\hline Oliveira et al. (2011) & 2001 to 2006 & $\begin{array}{c}\text { Spatial } \\
\text { Econometrics }\end{array}$ & $\begin{array}{l}\text { Municipalities of } \\
\text { Amazônia Legal }\end{array}$ & $\sqrt{ }$ & $\sqrt{ }$ \\
\hline $\begin{array}{c}\text { Soares \& Almeida } \\
(2018)\end{array}$ & ---- & $\begin{array}{c}\text { Development of } \\
\text { KPIs }\end{array}$ & Brazil & - & $\sqrt{ }$ \\
\hline
\end{tabular}

Source: Based on research data.

\section{Methodology}

\subsection{Data}

This research analyzes the annual deforestation of the forest remnants of Atlantic Forest and natural non-forest areas - DEF, in acres. These data are from the project "Aqui tem Mata?", an application elaborated with data from the "Atlas of the Atlantic Forest", from the Fundação SOS Mata Atlântica (2020b) that presents graphs and interactive maps with updated information on the state of conservation of the forests, mangroves and restingas in all 3,429 Brazilian municipalities with remnants of the Atlantic Forest.

In the survey that analyzes the changes in forest cover, two limitations stand out: the presence of cloud cover, which impairs image processing, hence there may be areas not observed; and, the limitation of the mapping, which requires a minimum area of 3 acres, both for the detection of forest changes and for the identification of forest remnants. For monitoring purposes, areas with deforestation of fewer than 3 acres are marked as evidence of deforestation and will be observed again in new versions of the reports (Fundação SOS Mata Atlântica, 2020a). 
The research comprising the period from 2011 to $2017^{5}$ in the state of Ceará resulted in 61 municipalities monitored and distributed among five of the seven mesoregions of Ceará (Figure 1). Mesoregion 1 comprises 26 monitored municipalities (50.51\% of the total), followed by mesoregion 2 with 20 municipalities (28\%) and mesoregions 3, 5, and 7 together with 14 monitored municipalities (21.49\%).

The deforestation process might happen because of several activities, especially anthropic ones. Based on this, we used information from agriculture, consumption, demography, economic and tax, labor market, and geoenvironmental aspects, from different sources, as shown in Table 2.

The economy, population, and territory information is extracted from the Brazilian Institute of Geography and Statistics (IBGE) and includes GDPpc, its quadratic and cubic form, the Gross Added Value of Agriculture ( $G A V_{p c}^{a g r o}$ ), the Value of Extractive Production (VEP), Population Density (POPD) and the number of cattle (CAT).

The number of workers employed in the sectors of Agriculture, Livestock and Related Services and Forest Production (Emp. primary $)$ comes from the Annual List of Social Information (RAIS), of the Ministry of Labor (Brasil, 2017). While Municipal Electricity Consumption (ECPC), is provided by Ente Nazionale per L'energia Elletrica (Ente Nazionale per L'energia Elletrica, 2017).

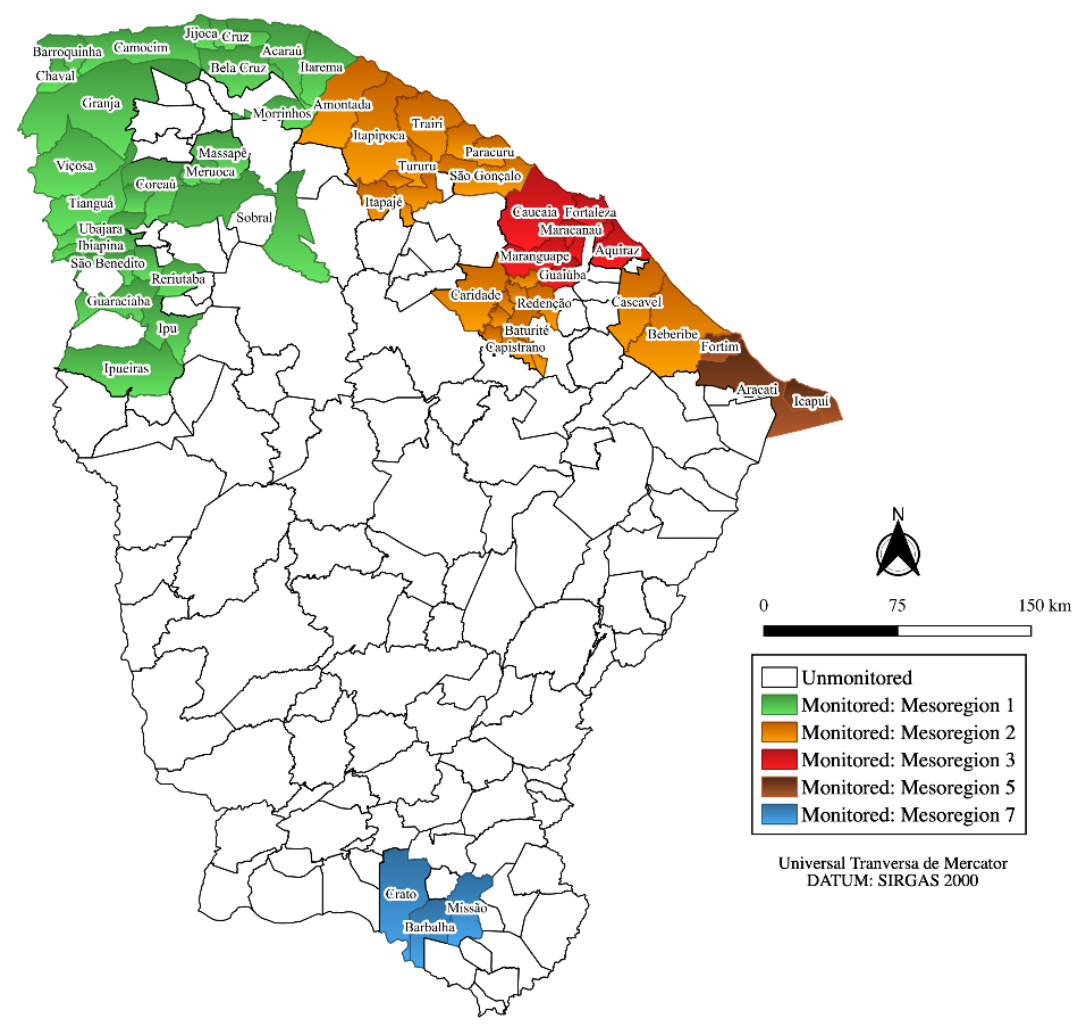

Figure 1. Municipalities in Ceará monitored by the "Aqui tem Mata?" Program. Source: Based on research data

Tax information such as the Municipal Participation Fund (FPM), the Tax on Circulation of Goods and Services (ICMS), and Tax Revenue (RT) were extracted from the Public Sector's Accounting and Tax Information System (Sistema de Informações Contábeis e Fiscais do Setor Público Brasileiro, 2017), created by the National Treasury Secretariat (STN).

${ }^{5}$ During the preparation of this survey, the municipal GDP for the year 2018 had not been released, so there is a limitation on the use of data on deforestation for the year 2017. 
The total annual observed Rainfall (RAIN) is from the Cearense Foundation for Meteorology and Water Resources (Fundação Cearense de Meteorologia e Recursos Hídricos, 2020) and the delimitation of the Semi-Arid Region (SAR) in Brazil is from the Ministry of Integration (Brasil, 2018). As for the protected areas, dummy variables were generated to account for the presence of the municipal, state, and federal terrestrial Conservation Units (CU) located in Ceará's territory (Brasil, 2020).

In addition, the municipal base has variables that derive from the crossing of two indicators from different sources. These variables indicate whole values as a proportion of the population or area of the municipality. Economic, tax, and electricity consumption information are expressed in per capita values, whereas cattle and population are expressed in terms of the municipal area.

Table 2. Description of variables and data sources.

\begin{tabular}{|c|c|c|c|}
\hline Variable & Description & Unit & Source \\
\hline DEF & $\begin{array}{l}\text { Deforested area of the forest remnants of the Atlantic Forest } \\
\text { and natural non-forest areas }\end{array}$ & Acres & $\begin{array}{l}\text { Fundação SOS Mata } \\
\text { Atlântica (2020b) }\end{array}$ \\
\hline GDPpc & Municipal GDP per capita & $\mathrm{R} \$$ in 2015 & $\begin{array}{l}\text { Instituto Brasileiro } \\
\text { de Geografia e } \\
\text { Estatística (2017a) }\end{array}$ \\
\hline$(G D P p c)^{2}$ & Quadratic municipal GDP per capita & - & \multirow{2}{*}{$\begin{array}{l}\text { Derived from } \\
\text { GDPpc }\end{array}$} \\
\hline$(\mathrm{GDPpc})^{3}$ & Cubic municipal GDP per capita & - & \\
\hline$G A V_{p c}^{a g r o}$ & GAV of agriculture per capita & \multirow{2}{*}{$\mathrm{R} \$$ in 2015} & $\begin{array}{l}\text { Instituto Brasileiro } \\
\text { de Geografia e } \\
\text { Estatística (2017b) }\end{array}$ \\
\hline VEPpc & $\begin{array}{l}\text { Value of extractive production of charcoal, firewood, and } \\
\text { roundwood per capita }\end{array}$ & & $\begin{array}{l}\text { Instituto Brasileiro } \\
\text { de Geografia e } \\
\text { Estatística (2017c) }\end{array}$ \\
\hline POPD & $\begin{array}{l}\text { Ratio of absolute population and area occupied by that same } \\
\text { population }\end{array}$ & $\mathrm{hab} / \mathrm{km}^{2}$ & $\begin{array}{l}\text { Instituto Brasileiro } \\
\text { de Geografia e } \\
\text { Estatística (2017d) }\end{array}$ \\
\hline CAT & Ratio of herd size of cattle by municipal area & count $/ k^{2}$ & $\begin{array}{l}\text { Instituto Brasileiro } \\
\text { de Geografia e } \\
\text { Estatística (2020) }\end{array}$ \\
\hline Emp.primary & $\begin{array}{l}\text { Formal jobs in Agriculture, Livestock and Related Services + } \\
\text { Forestry Production }\end{array}$ & Count & Brasil (2017) \\
\hline $\mathrm{ECpc}$ & Municipal electricity consumption per capita & MWh pc & $\begin{array}{l}\text { Ente Nazionale per } \\
\text { L'energia Elletrica } \\
\qquad(2017)\end{array}$ \\
\hline FPMpc & Municipal Participation Fund per capita & & Sistema de \\
\hline ICMSpc & ICMS per capita & & Informações \\
\hline RTpc & Tax Revenue per capita & $\mathrm{R} \$$ in 2015 & $\begin{array}{l}\text { Contábeis e Fiscais } \\
\text { do Setor Público } \\
\text { Brasileiro (2017) }\end{array}$ \\
\hline RAIN & Total annual observed rainfall & $\mathrm{mm}$ & $\begin{array}{l}\text { Fundação Cearense } \\
\text { de Meteorologia e } \\
\text { Recursos Hídricos } \\
\text { (2020) }\end{array}$ \\
\hline SAR & $\begin{array}{l}1 \text { if municipality belongs to the semiarid region, } 0 \text { otherwise } \\
\text { (c.c) }\end{array}$ & & Brasil (2018) \\
\hline $\mathrm{CU}_{\text {municipality }}$ & 1 if the municipality has a municipal $C U, 0$ otherwise c.c & Dummy variable & Brasil (2020) \\
\hline $\mathrm{CU}_{\text {state }}$ & 1 if the municipality has a state $C U, 0$ otherwise c.C & & \\
\hline $\mathrm{CU}_{\text {federal }}$ & 1 if the municipality has a federal $C U, 0$ otherwise c.c & & \\
\hline
\end{tabular}

Source: Based on research data.

\subsection{Empirical Model}

To estimate the EKC applied to the deforestation of forest remnants and non-forest natural areas in Ceará, we considered the model that includes the GDPpc variable in its squared and cubic forms, as follows: 


$$
D E F_{i t}=\beta_{0}+\beta_{1} G D P p c_{i, t-1}+\beta_{2}(G D P p c)_{i, t-1}^{2}+\beta_{3}(G D P p c)_{i, t-1}^{3}+\beta_{k} X_{i, t-1}+{ }_{i t}
$$

For which, $D E F_{i t}$ is the annual deforestation for each of the $i$ municipalities monitored by the "Aqui tem Mata?" program, where $i=1, \ldots, 61$. The subscript $t$ for the data set corresponds to the observed year $t=2011, \ldots, 2017$, the $G D P p c_{i, t-1}$ data set corresponds to the observed year denotes the level of economic activity of the i-th municipality in the previous year, and $X_{i, t-1}$ corresponds to the set of additional explanatory variables lagged by one year (Table 2). The data compose a balanced panel with 427 observations.

From this, the EKC format is related to the sign and significance presented by the coefficients $\left(\beta_{1}, \beta_{2}, \beta_{3}\right)$. A sufficient condition for the EKC to present a linear format occurs when $\beta_{1}>0$ or $\beta_{1}<0$, while $\beta_{2}=\beta_{3}=0$. When $\beta_{1}>0$ an increase in GDPpC is linearly related to deforestation. For the "Inverted-U" format, it is sufficient that $\beta_{1}>0, \beta_{2}<0$ and $\beta_{3}=0$, for the "U" format, $\beta_{1}\left\langle 0, \beta_{2}\right\rangle 0$ and $\beta_{3}=0$. Finally, in cases where $\beta_{1}>0, \beta_{2}<0$ and $\beta_{3}>0$ or $\beta_{1}\left\langle 0, \beta_{2}\right\rangle 0$ and $\beta_{3}<0$, the curve takes the form of " $\mathrm{N}$ " and " $\mathrm{N}$-inverted" respectively.

Note that, the dependent variable, the annual deforestation of the Atlantic Forest remnants and non-forest natural areas can be considered as a censored variable, as it is reasonable to assume that deforestation does not assume negative values, so we did not observe the variable of interest if it is below zero. In addition, the analysis of these data reveals that, of the 427 observations for deforestation, 347 are null observations (deforestation $<3$ acres), that is, there is an excess of zeros and not the absence of information.

When disregarding such facts (censorship and excess of zeros) the traditional estimates of Ordinary Least Squares will be inconsistent since the assumptions of the classical linear model are violated. A model that applies well to these problems is the Tobit model, initially proposed by Tobin (1958), suitable when the dependent variable is censored or truncated, in addition to these cases, it is suitable when the dependent variable assumes an excessive number of $\operatorname{zeros}^{6}$ (Calzolari et al., 2001). Thus, the Tobit model can be expressed as follows:

$Y_{i t}=\left\{\begin{array}{c}0, \text { if } Y_{i t}^{*} \leq 0 \\ Y_{i t}^{*}, \quad \text { if } Y_{i t}^{*}>0\end{array}\right.$

Where $Y_{i t}^{*}=X_{i t}^{\prime} \beta+_{i t}$ is observed only if strictly positive, $X_{i t}$ represents the vector of explanatory variables and the term ${ }_{i t} \sim N\left(0, \sigma^{2}\right)$ i.i.d and independent of $X_{i t}$, with $i=1, \ldots, N$ and $t=1, \ldots, T$. The probability density function when $Y$ is observed is (Amemiya, 1985):

$$
f\left(Y_{i t} \mid X_{i t} ; \theta\right)=\left\{\begin{array}{c}
0, \text { if } Y_{i t}<0 \\
\Phi\left(-X_{i t}^{\prime} \beta / \sigma_{\varepsilon}\right), \text { if } Y_{i t}=0 \\
\phi\left(\left(Y_{i t}-X_{i t}^{\prime} \beta\right) / \sigma_{\varepsilon}\right), \text { if } Y_{i t}>0
\end{array}\right.
$$

Where $\Phi$ is the cumulative distribution function and $\phi$ is the probability density function of the standard normal distribution. When considering the model for panel data, the error term it can be decomposed in (Calzolari et al., 2001):

${ }^{6}$ Do not confuse with models for inflated zero count data: Zero-Inflated Poisson (ZIP) or Zero-Inflated Negative Binomial (ZINB). 


$$
{ }_{i t}=\alpha_{i}+\lambda_{t}+u_{i t}
$$

Where $\alpha_{i}$ are the individual effects (unobservable characteristics specific to unit $i$ that are considered constant over time) interpreted as fixed parameters or as random variables, whereas $\lambda_{t}$ is the effect of time (unobservable characteristics in period t, constant for all units cross-section in the sample) and $u_{i t}$ is a random term that varies over time and with individuals, in addition $u_{i t}$ is not correlated over time (Calzolari et al., 2001).

Tobit regression models with panel data can take two forms, fixed effects or random effects. According to Cameron \& Trivedi (2005), in smaller panels $(T<8)$ the fixed effects estimator is not consistent, so the random-effects model is the most suitable:

$Y_{i t}^{*}=\alpha_{i}+X_{i t}^{\prime} \beta+u_{i t}$

Where, $\alpha_{i} \sim N\left(0, \sigma_{\alpha}^{2}\right)$ i.i.d, $u_{i t} \sim N\left(0, \sigma_{u}^{2}\right)$ i.i.d, with $u_{i t}$ independent of $\alpha_{i}$, it is assumed that from the expression 4 the term $\lambda_{t}=0 \forall t$. The Equation 5 can be written as (Calzolari et al., 2001):

$Y_{i t}^{*}=\sigma_{\alpha} \alpha_{i}+X_{i t}^{\prime} \beta+\sigma_{u} u_{i t}$

Where $\alpha_{i} \sim N(0,1)$ i.i.d independent of $u_{i t}$, with $u_{i t} \sim N(0,1)$ i.i.d. Due to the individual effect, the observations on the dependent variable for each individual $i$ are correlated. However, linked to the individual effect $\alpha_{i}$, the conditional joint density function can be written as (Gourieroux \& Monfort, 1993):

$$
f\left(Y_{i} \mid X_{i}, \alpha_{i} ; \theta\right)=\prod_{t: Y_{i t}>0} \frac{1}{\sigma_{u}} \phi\left(\frac{Y_{i t}-X_{i t}^{\prime} \beta-\sigma_{\alpha} \alpha_{i}}{\sigma_{u}}\right) * \prod_{t: Y_{i t}=0} \Phi\left(\frac{-X_{i t}^{\prime} \beta-\sigma_{\alpha} \alpha_{i}}{\sigma_{u}}\right)
$$

$\Phi$ and $\phi$ are the cumulative distribution function and the probability density function with the distribution $N(0,1)$. Since the individual effects $\alpha_{i}$ are not observable, the equation $(6)$ cannot be used in the inferences. To obtain maximum unconditional likelihood, it is necessary to integrate the individual effect $\alpha_{i}$ :

$f\left(Y_{i} \mid X_{i} ; \theta\right)=\int f\left(Y_{i} \mid X_{i}, \alpha_{i} ; \theta\right) d P^{\alpha}(\alpha)$

A satisfactory solution for the integral (7) is the procedure via numerical integration. Alternatively, the integral (7) can be approximated using replicated simulations, thus obtaining a simulated likelihood function to be maximized to obtain a simulated maximum likelihood estimator (Calzolari et al., 2001). Finally, as additional analyzes to the Tobit regression with random effects, there will be tested EKC with specifications of the GDPpc variable in its squared and cubic form for Tobit models with stacked or pooled Tobit data (base models).

\section{Results and Discussion}

The results are presented and discussed in three subsections that concentrate the analysis of the descriptive results, followed by the remaining and deforested areas and, finally, the econometric results are presented from the EKC specifications with GDPpc term in the quadratic and cubic forms, estimated by pooled Tobit and Tobit regressions with random effects. 


\subsection{Descriptive Data Analysis}

Table 3 presents some descriptive statistics for the data set. In general, all variables showed a positive percentage variation in the range from 2011 to 2017, except for cattle farming, the percentage of jobs in the primary sector of the economy concerning the total of formal jobs and precipitation.

The analysis of deforestation reveals an annual average of 6.93 acres/ municipality, with a maximum deforested extension of 375 acres in the municipality of Trairi (west coast of the state of Ceará). Of these observations, a large part (81\%) refers to deforestation below 3 acres, so there are 347 null observations. Despite this fact, deforestation in these regions may be occurring due to the "ant effect", deforestation small enough that the satellite does not capture its presence.

Regarding the economic information, the GDPpc stands out, with an average of $\mathrm{R} \$ 10,000$, with a minimum of $R \$ 2,700$ for the city of Tururu and a maximum of $R \$ 71,000$ in São Gonçalo do Amarante (SGA). For $G A V_{p c}^{a g r o}$ the average was $\mathrm{R} \$ 1.1$ thousand, with a minimum registration in the city of Fortaleza and maximum value in Missão Velha. VEPpc, on the other hand, has an average of $\mathrm{R} \$ 6.87$, with a maximum per capita value in Frecheirinha ( $\mathrm{R} \$ 122.48)$.

Concerning $P O P D$, the average is 263 inhabitants per $\mathrm{km}^{2}$, with the maximum density in the city of Fortaleza (capital of the state of Ceará) and minimum in the municipality of Granja. Cattle farming has an average of 14.60 heads $/ \mathrm{km}^{2}$, with minimum and maximum records in the mountain towns of Guaramiranga, with 2.50 heads $/ \mathrm{km}^{2}$, and Maranguape, with 34.41 heads $/ \mathrm{km}^{2}$, located in the Metropolitan Region of Fortaleza (RMF).

As for jobs in the primary sector of the economy, there is low participation in the total of formal jobs, with a greater proportion (> 45\%) in the municipality of Icapuí (east coast). In relation to ECpc, the average is $0.98 \mathrm{MWh}$, with the minimum consumption in the city of Granja and maximum in São Gonçalo do Amarante (SGA). Finally, regarding the tax information, the averages of FPMpc, ICMSpc, and $R T p c$ were, respectively, $R \$ 560.65, R \$ 212.88$, and $R \$ 111.24$. We highlight the municipality of SGA, which has the largest metrics related to GDPpc, ECpc, ICMSpC, and RTpc, possibly due to the presence of Pecém Industrial and Port Complex (CIPP) in the region.

Table 3. Descriptive Statistics, 2011-2017.

\begin{tabular}{|c|c|c|c|c|c|}
\hline & Average & Standard Deviation & Minimum & Maximum & $\Delta \%(2011-2017)$ \\
\hline DEF & 6.93 & 31.08 & 0.00 & 375.00 & $58.68 \%$ \\
\hline GDPpc & $10,056.60$ & $8,453.16$ & $2,751.99$ & $71,026.16$ & $153.27 \%$ \\
\hline$G A V_{p c}^{\text {agro }}$ & $1,148.80$ & $1,102.73$ & 11.23 & $8,899.82$ & $58.00 \%$ \\
\hline VEPpc & 6.87 & 11.65 & 0.00 & 122.48 & $16.76 \%$ \\
\hline POPD & 263.00 & $1,052.56$ & 19.61 & $8,343.06$ & $6.82 \%$ \\
\hline CAT & 14.60 & 6.76 & 2.50 & 34.41 & $-22.50 \%$ \\
\hline Emp.primary & 5.07 & 9.72 & 0.00 & 71.41 & $-1.60 \%$ \\
\hline ECpc & 0.98 & 0.91 & 0.32 & 6.87 & $16.47 \%$ \\
\hline FPMpc & 560.65 & 296.60 & 0.00 & $2,681.13$ & $153.20 \%$ \\
\hline ICMSpc & 212.88 & 185.09 & 0.00 & $1,283.49$ & $228.47 \%$ \\
\hline $\mathrm{RTpc}$ & 111.24 & 196.27 & 0.00 & $2,245.39$ & $308.86 \%$ \\
\hline RAIN & 916.18 & 381.01 & 19.00 & $2,382.00$ & $-30.95 \%$ \\
\hline
\end{tabular}

Source: Elaborated by the authors.

The correlation matrix is presented in Appendix A, from which a high correlation is observed between GDPpc and ICMSPc and between GDPpc and RTpc, respectively, 0.806 and 0.842. As a result, we decided to consider only GDPpc in the econometric model.

\subsection{Analysis of the accumulated deforestation and remnants of the native forest}

Figure 2 shows the spatial distribution of the accumulated deforestation of the Atlantic Forest and its associated ecosystems from 2011 to 2019, as well as the proportion of these 
domains in relation to the municipal area, in 2019 (the most recent year for both information). For deforestation, stronger colors show greater degradation, therefore the municipalities of Cruz and Trairi stand out, as they account for $42 \%$ of the total deforested in nine years.

In addition, deforestation is located mainly on the coast, especially in the municipalities of the western portion of the state (Acaraú, Amontada, Cruz, Itarema, Paracuru, Paraipaba, and Trairi). The recent deforestation on the west coast may be due to the configuration of these places as new tourist destinations, with the allotment of land for the construction of vacation homes and resorts, given the low cost of land in some places. On the other hand, 34 monitored municipalities with deforestation of fewer than 3 acres are identified. Despite this fact, it is necessary to take into account the "ant effect" imposed by the advance of housing and the expansion of urban infrastructure.

For the coverage of the native forest, stronger colors show a greater proportion of the Atlantic Forest areas and natural non-forest areas in relation to the territorial extension. Thus, seven municipalities have more than $20 \%$ of the territory covered by native forest, namely: Barroquinha, Cruz, Guaramiranga, Jijoca de Jericoacoara, Mulungu, Pacoti and Paracuru. However, most of the monitored municipalities are in the range of native forests below $10 \%$ of the municipal territory.

Accumulated Deforestation (2011 - 2019)

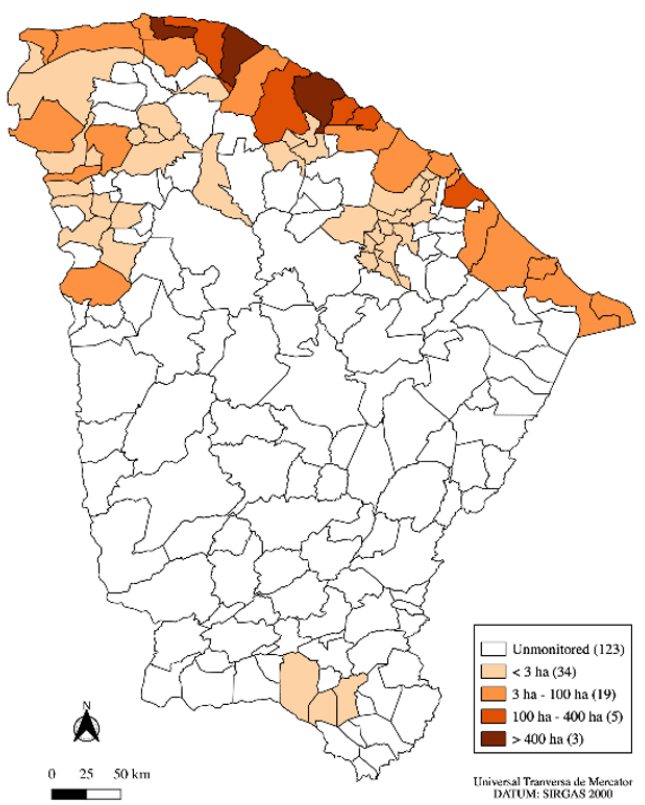

Native Forest Coverage (2019)

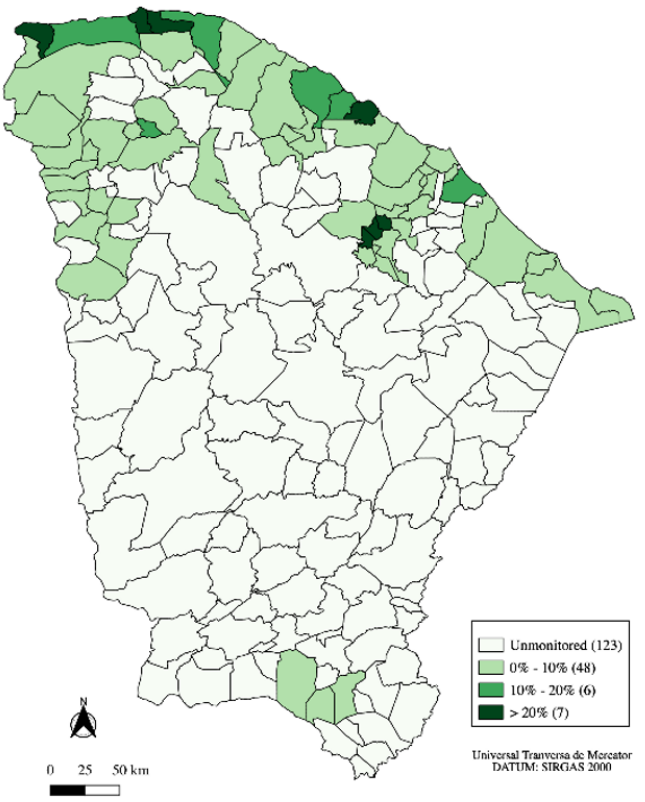

Figure 2. Accumulated deforestation and native forest coverage in the state of Ceará. Source: Elaborated by the authors.

\subsection{Estimates for the Environmental Kuznets Curve}

Concerning the EKC, the quadratic and cubic versions were estimated by pooled Tobit and Tobit regression models with random effects. Table 4 presents these results, among the base model (pooled tobit) and according to the Akaike Information Criterion (AIC), the model with the best fit $(1,093.693$ against $1,090.122)$ is the one that incorporates the cubic relationship between deforestation and GDPPC.

For this model, the variables POPD, CAT, ECPC, FPMPC, and the dummies for the semiarid and federal CUs are significant. Population density shows a negative relationship with the annual deforested area, denoting that municipalities with large population densities deforest have fewer areas of native forest. Even with the unexpected result, we can observe that in the scientific literature, there is no consensus on the signal obtained for this variable, as some studies have found a positive (Cropper \& Griffiths, 1994), negative (Teixeira et al., 2012) or they 
did not even observe a relationship (Oliveira et al., 2011; Colusso et al., 2012) between deforestation and population density.

Cattle ranching presented an opposite sign than the expected (positive), indicating that the presence of this agricultural activity contributes to less deforestation. Colusso et al. (2012) corroborate the negative relationship between cattle and deforestation in the 1,306 municipalities that present the Cerrado area in Brazil for 2008. On the other hand, these results contradict those found by Oliveira et al. (2011) and Barros \& Stege (2019).

The increase in electricity consumption per capita is negatively related to the annual deforestation that extends among the 61 municipalities analyzed in Ceará. Although the researches that evaluate the EKC hypothesis do not directly address the relationship between energy consumption and deforestation, they do so for $\mathrm{CO}_{2}$ emissions, which is a proxy for deforestation. As a consequence, the results obtained indicate that $\mathrm{CO}_{2}$ emissions increase when the ECPC rises (Biage \& Almeida, 2015; Carvalho \& Almeida, 2010), which is the opposite of the result of this research.

The FPMPC is negatively related to deforestation, that is, municipalities that receive a greater transfer of this resource deforest less than the others, which is in line with expectations. The transfer of this resource to the municipalities is linked to the population factor and the GDPpc so that more populous cities with high income per capita receive greater transfers. As a result, they are more developed and have significant expenses in various services offered to the population, such as education and health, services without a direct relationship to the forestry sector. Also, it is reasonable to assume that more developed areas have fewer green areas for deforestation.

The significant geoenvironmental dummies were the semiarid region and the federal CUs. The coefficients showed a negative sign, leading to believe that the municipalities inserted in regions of semi-arid climate deforest less of the forest and non-forest remnants of the Atlantic Forest in relation to those with a humid tropical climate. The municipalities with less federal CUs deforest, that is, the presence of these areas of environmental protection does not eliminate the activity of deforestation in these regions, especially illegal deforestation.

Concerning EKC, the fact that $(G D P p C)^{3}$ is positive suggests that deforestation of the remaining native forest increases when GDPpc increases, in Ceará. This is due to the EKC's " $\mathrm{N}$ " format, in which additional increases in economic activity (GDPpC) intensify the deforestation of the Atlantic Forest. The estimated inflection points are $\mathrm{R} \$ 22$ thousand and $\mathrm{R} \$ 60$ thousand, with the local maximum ( $R \$ 22$ thousand) covering $91.8 \%$ of the municipalities (responsible for $87 \%$ of the deforested area), which belong to the ascending part of the curve. Four municipalities are in the region of $R \$ 22$ thousand $\leq G D P p c \leq R \$ 60$, representing just over $11 \%$ of deforestation. And, finally, in the region with an upward slope, with GDPpC $\geq \mathrm{R} \$ 60$ thousand is the municipality of SGA.

Analyzing the results of the pooled Tobit versus Tobit models with random effects, it appears that the likelihood ratio test (LR) for Tobit models in panel data rejects $H_{0}: \sigma_{\alpha}=0$, that is, one must analyze the results of the Tobit regression with random effects. The Akaike Information Criterion (AIC) shows that the Tobit models with random effects perform better than the base models (pooled tobit). As for the model, the one that presents the cubic relationship between deforestation and GDPpc has the best adjustment $(1,022.569$ against 1,018.819).

In terms of effect, it appears that the demographic pressure exerted by population density is negatively related to deforestation, that is, increments in POPD soften the activity of deforestation. This relationship was expected to have a positive effect; however, it is possible that due to the initial expansion of the urban network, some green areas will give way to real estate production and urban infrastructure works. Thus, with the low availability of green areas, small urban forest fragments must be preserved.

As for the cattle herd, the effect is negatively related to the annual deforested area in the monitored municipalities. The intuition for choosing this variable into the model is that, with the expansion of pasture areas, changes in forest cover would occur. However, looking at 
national production, it can be seen that the state of Ceará accounts for just over $1 \%$ of the Brazilian market, in contrast, the states of Goiás and Mato Grosso account for $10.6 \%$ and $14 \%$ respectively of the bovine production about 2018 (Instituto Brasileiro de Geografia e Estatística, 2020), raising suspicions that livestock activity is not widespread in Ceará.

In addition to this fact, the data for Ceará cattle breeding reveal a gradual reduction of this activity in the state. It is also added that cattle ranching maybe being practiced mainly in the morphoclimatic domain of the Caatinga of Ceará, so cattle farming would not be directly related to annual deforestation in the domains of the Atlantic Forest and associated ecosystems.

Table 4. Results on the deforestation of the forest remnants of the Atlantic Forest and non-forest natural areas in Ceará, 2011-2017.

\begin{tabular}{|c|c|c|c|c|}
\hline \multirow{2}{*}{ Model } & \multicolumn{2}{|c|}{ Pooled Tobit } & \multicolumn{2}{|c|}{ Random Effects Tobit } \\
\hline & $(\text { GDPpc })^{2}$ & $(\mathrm{GDPpc})^{3}$ & $(\mathrm{GDPpc})^{2}$ & $(\mathrm{GDPpc})^{3}$ \\
\hline Constant & $119.027 *$ (52.379) & 77.937 (55.170) & $52.377(66.803)$ & 6.986 (69.655) \\
\hline GDPpc & $0.017 *(0.003)$ & $0.025 *(0.005)$ & $0.012 *(0.003)$ & $0.021 *(0.005)$ \\
\hline$(G D P p c)^{2}$ & $-3.00 e^{-07 \star}\left(6.21 e^{-08}\right)$ & $-7.78 \mathrm{e}^{-07 \star}\left(2.44 \mathrm{e}^{-07}\right)$ & $-2.03 \mathrm{e}^{-07 \star}\left(5.64 \mathrm{e}^{-08}\right)$ & $-6.27 \mathrm{e}^{-07 \star}\left(2.16 \mathrm{e}^{-07}\right)$ \\
\hline$(\mathrm{GDPpc})^{3}$ & & $6.32 \mathrm{e}^{-12 \star}\left(2.89 \mathrm{e}^{-12}\right)$ & & $5.10 \mathrm{e}^{-12 \star}\left(2.34 \mathrm{e}^{-12}\right)$ \\
\hline$G A V_{p c}^{a g r o}$ & $-0.014(0.010)$ & $-0.015(0.010)$ & $-0.018(0.013)$ & $-0.018(0.012)$ \\
\hline VEPpc & $-0.394(0.075)$ & $-0.153(0.749)$ & $0.312(0.717)$ & $0.594(0.718)$ \\
\hline POPD & $-0.032 *(0.008)$ & $-0.031 *(0.008)$ & $-0.028 *(0.013)$ & $-0.028 *(0.013)$ \\
\hline CAT & $-9.303 *(1.727)$ & $-9.093^{*}(1.708)$ & $-7.382 *(2.136)$ & $-7.126 *(2.121)$ \\
\hline Emp.primary & $0.806(0.998)$ & $0.713(1.003)$ & $0.881(1.378)$ & $0.797(1.367)$ \\
\hline $\mathrm{ECpc}$ & $-30.776 *(10.706)$ & $-27.688^{*}(10.686)$ & $-16.143(12.591)$ & $-15.455(12.263)$ \\
\hline FPMpc & $-0.111 *(0.034)$ & $-0.115 *(0.034)$ & $-0.046(0.037)$ & $-0.063(0.038)$ \\
\hline RAIN & $0.019(0.017)$ & $0.021(0.017)$ & $0.018(0.013)$ & $0.021(0.013)$ \\
\hline SAR & $-95.389 *(25.218)$ & $-95.859 *(24.965)$ & $-82.405^{\star}(41.542)$ & $-77.345(40.972)$ \\
\hline $\mathrm{CU}_{\text {municipality }}$ & $-37.481(41.967)$ & $-40.106(41.590)$ & 8.605 (70.393) & $4.369(69.521)$ \\
\hline $\mathrm{CU}_{\text {state }}$ & $14.326(13.391)$ & $12.964(13.348)$ & $20.110(24.782)$ & $19.179(23.840)$ \\
\hline $\mathrm{CU}_{\text {federal }}$ & $-37.698^{*}(12.977)$ & $-36.512^{*}(12.898)$ & $-33.395(22.782)$ & $-33.896(22.575)$ \\
\hline /sigma & $76.303(6.49)$ & $75.718(6.43)$ & & \\
\hline$/$ sigma_ $^{\alpha}$ & & & $62.537 *(11.096)$ & $61.792 *(10.918)$ \\
\hline /sigma_u & & & $48.907 *(4.235)$ & $48.326 *(4.181)$ \\
\hline LR & & & $73.120 *$ & $73.300 *$ \\
\hline AIC & $1,093.693$ & $1,090.122$ & $1,022.569$ & $1,018.819$ \\
\hline Pseudo R2 & 0.070 & 0.087 & & \\
\hline$N^{\circ}$ Obs. & 366 & 366 & 366 & 366 \\
\hline \multirow[t]{2}{*}{ Inflexion Point } & $28,333.333$ & Máx: 21,923.520 & $29,556.650$ & Máx: 23,458.169 \\
\hline & & Mín: 60,143.980 & & Mín: 58,497.320 \\
\hline Functional Form & "Inverted-U" & “N" & "Inverted-U" & “N" \\
\hline
\end{tabular}

Source: Based on research data. Notes: Robust standard errors to heteroscedasticity in parentheses. * denotes significance at the $5 \%$ level.

As $(G D P p C)^{3}$ is positive, the EKC has an " $\mathrm{N}$ " shape, which implies that the reduction in deforestation, when economic activity is growing, is transitory (even the "Inverted-U" part), because as additional increases in GDPpc occur, deforestation increases, as illustrated in Figure 3. The inflection points found were $R \$ 23$ thousand and $R \$ 58$ thousand.

The local maximum point of the pooled Tobit model ( $R \$ 23$ thousand), accounts for $91.8 \%$ of the municipalities in the sample, which is responsible for $87 \%$ of the deforested area. When comparing the average GDPpc of the municipalities to the local maximum ( $R \$ 10,000$ against $R \$ 23,000$ ), we observed that in the short term these regions will still be on the rising part of the curve and, therefore, it is still possible that these municipalities adopt unilateral strategies 
(or even in a coordinated way) to flatten the deforestation curve and, thus, preserve the remaining forest areas of the Atlantic Forest in Ceará, as well as the non-forest natural areas.

In the descending part of the curve, $\mathrm{R} \$ 23$ thousand $\leq \mathrm{GDPpc} \leq \mathrm{R} \$ 58$ thousand, there are four municipalities - Fortaleza, Aquiraz, Eusébio, and Maracanaú (the last three in the RMF), which account for just over $11 \%$ of deforestation. After the local minimum point (GDPpc $\geq \mathrm{R} \$ 58$ thousand), in the ascending part of the curve, the municipality of São Gonçalo do Amarante is found, an important economic region in Ceará for contemplating the CIPP and also for having port and steel facilities, thermoelectric, wind farms and the Export Processing Zone (ZPE).

From the EKC " $\mathrm{N}$ " shape, it can be inferred that the continuous increase in municipal economic activity, as measured by GDPpc, positively affects deforestation. And, as it increased again, it cannot be said that deforestation levels reached an absolute maximum in the region studied. The result is similar to that of Colusso et al. (2012) who observed an EKC in "N" format for the relationship between economic growth and environmental degradation in the Cerrado biome. However, the different relationships between deforestation and pc income, established by the "Inverted-U" format (Ferreira \& Coelho, 2015; Barros \& Stege, 2019) and "Inverted-N" (Oliveira et al., 2011; Rodrigues et al., 2016) lead to the conclusion that the "Inverted-U" hypothesis for deforestation cannot be consolidated in the literature as a stylized fact.

Finally, regarding the EKC hypothesis, we can state that the "Inverted- $U$ " format is only verified in models with a quadratic specification of GDPpc. By incorporating the cubic term of $G D P p c, E K C$ is configured in the form of " $\mathrm{N}$ ", breaking the paradigm that economic activity alone generates automatic protection for the environment, vis a vis sustainable development. On the contrary, the evidence found by this research points to the existence of a cyclical movement in the EKC in the remaining forest areas of the Atlantic Forest and non-forest natural areas in Ceará.

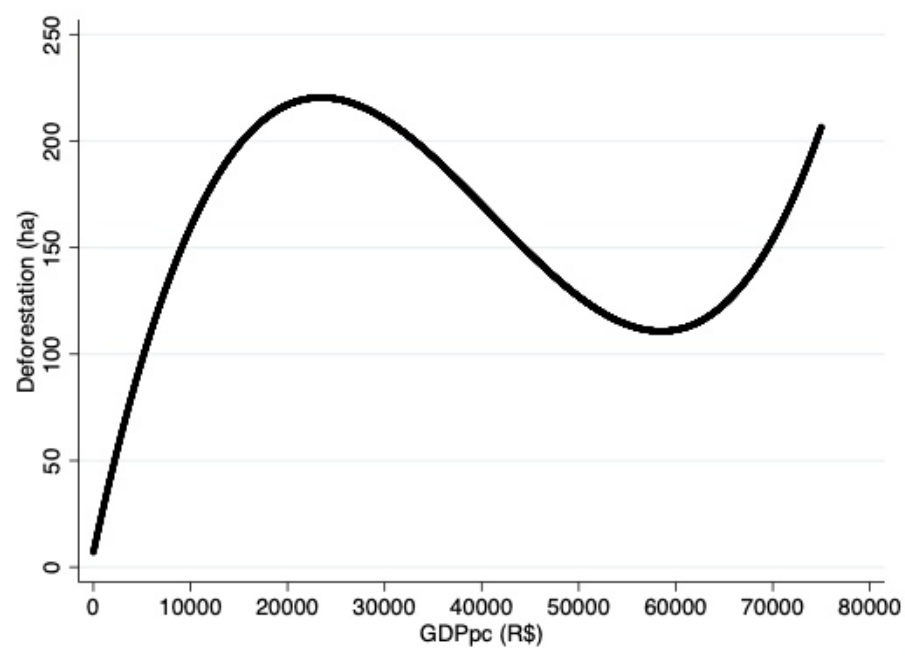

Figure 3. Environmental Kuznets Curve for the deforestation of the forest remnants of the Atlantic Forest and non-forest natural areas in Ceará, 2011-2017. Source: Based on research data.

\section{Conclusion}

This research investigated the hypothesis of "U-inverted" for the EKC between GDPpc and annual deforestation of the forest and non-forest remnants of the Atlantic Forest in a sample of 61 municipalities from Ceará, monitored by the program “Aqui tem Mata?" from 2011 to 2017.

The causes of deforestation are conditioned to several activities, especially anthropic ones. To contemplate these relationships, the characteristics associated with agriculture, consumption, demography, economic and tax information, the labor market, and geoenvironmental aspects are used. Understanding these relationships can assist in 
understanding the region's sustainable development process, therefore slowing deforestation activities in Atlantic Forest domains in Ceará.

The relationship between deforestation and economic activity is verified in the form of " $\mathrm{N}$ ". In the ascending phase of the EKC (GDPpC $\leq \mathrm{R} \$ 23$ thousand), deforestation is increasing for low levels of GDPpc. On the other hand, in the region of $R \$ 23$ thousand to $R \$ 58$ thousand of GDPpc, deforestation decreases as GDPpc rises, thus increasing again for GDPpc values above $R \$ 58$ thousand. Another relevant aspect is that $91.8 \%$ of the municipalities are in the first rising phase of the curve since the average GDPpc of the State is $R \$ 10,000$, which suggests that in the short term, most of these municipalities will not reach the intermediate range of the EKC ( $R \$ 23$ thousand $\leq G D P p c \leq R \$ 58$ thousand), where dismantling decreases with the increase in economic activity. The EKC analyzes indicate that the GDPpc level is a crucial factor for deforestation.

Regarding the demographic pressure exerted by population density and by cattle farming, it appears that they reduce deforestation. However, it is worth mentioning that cattle ranching is not so expressive in Ceará and that the expansion of pasture areas can occur in the Caatinga domains, having no direct relationship with the Atlantic Forest and its natural non-forest forms. For population density, the effect can be associated with the preservation of forest fragments in urban and neighboring areas, due to the low availability of green areas in the region.

Given these results, the EKC's " $N$ " shape reveals a municipal behavior, in which economic development would not be aligned with the sustainable development of forest resources, since only four cities would be in the middle part of EKC, whereas, others 56 cities would still be in the first phase of the curve, with an intense relationship between economic activity and deforested area. Therefore, we concluded that the increase in GDPpC alone is not a factor that promotes an improvement in environmental quality.

The development of new technologies, as well as the unilateral efforts of the municipalities, enable to preserve the forest remnants and non-forest natural areas of the Atlantic Forest, thus reducing deforestation in the region, especially illegal deforestation. It is worth mentioning that the monitoring of these areas can assist in the design of public policies aimed at the sustainable use of natural resources and reduction of deforestation levels, as forests and associated ecosystems offer different environmental services and also, the protection of these wild habitats can prevent the transmission of zoonoses, due to the more direct interaction between humans and animals promoted by environmental suppression.

\section{References}

Almeida, M. G., \& Lobato, T. C. (2019). A curva de Kuznets ambiental para a região norte do Brasil entre os anos de 2002 a 2015. Economia \& Região, 7(1), 7-25.

Amemiya, T. (1985). Advanced econometrics (pp. 536). Cambridge, MA: Harvard University Press.

Barros, P. H. B., \& Stege, A. L. (2019). Deforestation and human development in the Brazilian agricultural frontier: an environmental Kuznets curve for MATOPIBA. Revista Brasileira de Estudos Regionais e Urbanos, 13(2), 161-182.

Biage, M., \& Almeida, H. J. F. (2015). Desenvolvimento e impacto ambiental: uma análise da curva ambiental de Kuznets. Pesquisa e Planejamento Economico, 45(3), 505-556.

Brasil. Ministério da Integração - MI. (2018). Nova delimitação Semiárido. Retrieved in 2020, August 9 , from https://www.gov.br/sudene/images/arquivos/semiarido/arquivos/Relação_de_Municípios_Semiárido. pdf

Brasil. Ministério do Meio Ambiente - MMA. (2020). Painel Unidades de Conservação. Retrieved in 2020, August 9, from https://app.powerbi.com/view?r=eyjrljoiMDNmZTA5Y2ItNmFkMy00Njk2LWI4YjYtZDJINzFkOGM5NW Q4liwidCI6ljiMjY2ZmE5LTNmOTMtNGJiMS05ODMwLTYZNDY3NTJmMDNINCIsImMiOjF9

Brasil. Ministério do Trabalho - MTB. (2017). A Relação Anual de Informações Sociais - RAIS. Retrieved in 2020, August 9, from http://www.rais.gov.br/sitio/index.jsf

Calzolari, G., Magazzini, L., \& Mealli, F. (2001). Simulation-based estimation of Tobit model with random effects (pp. 349-369). Germany: MPRA. 
Cameron, A. C., \& Trivedi, P. K. (2005). Microeconometrics: methods and applications (pp. 1058). New York: Cambridge University Press.

Carvalho, T. S., \& Almeida, E. S. (2010). A hipótese da curva de Kuznets ambiental global: uma perspectiva econométrico-espacial. Estudos Econômicos, 40(3), 587-615.

Castelo, T. B., Adami, M., Almeida, C., \& Almeida, O. T. (2018). Governos e mudanças nas políticas de combate ao desmatamento na Amazônia. Revista Iberoamericana de Economía Ecológica, 28(1), 125148.

Colusso, M. V. S., Parré, J. L., \& Almeida, E. S. (2012). Degradação ambiental e crescimento econômico: a curva de Kuznets ambiental para o cerrado. Revista de Economia e Agronegócio, 10, 335-357.

Cropper, M., \& Griffiths, C. (1994). The Interaction of Population Growth and Environmental Quality. The American Economic Review, 84(2), 250-254.

Delazeri, L. M. M. (2016). Determinantes do desmatamento nos municípios do arco verde - Amazônia Legal: uma abordagem econométrica. Economia Ensaios, 30(2), 11-34.

Empresa Brasileira de Agropecuária - EMBRAPA. (2020). Sobre o MATOPIBA. Retrieved in 2020, June 30, from https://www.embrapa.br/tema-matopiba/sobre-o-tema

Ente Nazionale per L'energia Elletrica - ENEL. (2017). Companhia Energética do Estado do Ceará - COELCE. Retrieved in 2020, August 9, from https://www.enel.com.br/pt-ceara.html

Ferreira, M. D. P., \& Coelho, A. B. (2015). Desmatamento recente nos estados da Amazônia legal: uma análise da contribuição dos preços agrícolas e das políticas governamentais. Revista de Economia e Sociologia Rural, 53(1), 93-108.

Fundação Cearense de Meteorologia e Recursos Hídricos - FUNCEME. (2020). Portal Hidrológico do Ceará. Retrieved in 2020, August 9, from http://www.hidro.ce.gov.br/municipios/chuvas-diarias

Fundação SOS Mata Atlântica, \& Instituto Nacional de Pesquisas Espaciais - INPE. (2020a). Atlas dos remanescentes florestais da Mata Atlântica: período $2018-2019$ (pp. 61). São Paulo: INPE.

Fundação SOS Mata Atlântica, \& Instituto Nacional de Pesquisas Espaciais - INPE. (2020b). Aqui tem Mata? Retrieved in 2020, August 9, from https://aquitemmata.org.br/\#/

Gourieroux, C., \& Monfort, A. (1993). Simulation-based inference: a survey with special reference to panel data models. Journal of Econometrics, 59(1-2), 5-33.

Grossman, G., \& Krueger, A. (1995). Economic growth and the environment. The Quarterly Journal of Economics, 110(2), 353-377.

Instituto Brasileiro de Geografia e Estatística - IBGE. (2017a). Produto Interno Bruto dos Municípios. Retrieved in 2020, August 9, from https://www.ibge.gov.br/estatisticas/economicas/contasnacionais/9088-produto-interno-bruto-dos-municipios.html?t=downloads

Instituto Brasileiro de Geografia e Estatística - IBGE. (2017b). Sistema IBGE de Recuperação Automática SIDRA. Retrieved in 2020, August 09, from https://sidra.ibge.gov.br/tabela/5938

Instituto Brasileiro de Geografia e Estatística - IBGE. (2017c). Produção da Extração Vegetal e da Silvicultura - PEVS. Retrieved in 2020, August 09, from

https://www.ibge.gov.br/estatisticas/economicas/agricultura-e-pecuaria/9105-producao-daextracao-vegetal-e-da-silvicultura.html?=\&t=o-que-e

Instituto Brasileiro de Geografia e Estatística - IBGE. (2017d). Estimativas da População. Retrieved in 2020, August 09, from https://www.ibge.gov.br/estatisticas/sociais/populacao/9103-estimativas-depopul?=\&t=downloads

Instituto Brasileiro de Geografia e Estatística - IBGE. (2020). Pesquisa da Pecuária Municipal - PPM. Retrieved in 2020, August 09, from https://www.ibge.gov.br/estatisticas/economicas/9107producao-da-pecuaria-municipal.html?=\&t=downloads

Oliveira, R. C., Almeida, E., Freguclia, R. S., \& Barreto, R. C. S. (2011). Desmatamento e crescimento econômico no Brasil: uma análise da curva de Kuznets ambiental para a Amazônia Legal. Revista de Economia e Sociologia Rural, 49(3), 709-739.

Rodrigues, L. A., Cunha, D. A., Brito, L. M., \& Pires, M. V. (2016). Pobreza, crescimento econômico e degradação ambiental no meio urbano brasileiro. Revista Iberoamericana de Economía Ecológica, 26(1), 11-24.

Sistema de Informações Contábeis e Fiscais do Setor Público Brasileiro - SICONFI. (2017). Contas anuais. Retrieved in 2020, August 9, from http://www.tesouro.fazenda.gov.br/contas-anuais 
Deforestation of the Atlantic Forest in the state of Ceará: analysis of the Environmental Kuznets Curve from panel data, 2011 to 2017

Soares, L. R., \& Almeida, L. T. (2018). Desacoplamento de impactos ambientais no Brasil. Revista Iberoamericana de Economía Ecológica, 28(2), 21-43.

Teixeira, R. F. A. P., Bertella, M. A., \& Almeida, L. T. (2012). Curva de Kuznets ambiental para o estado do mato grosso. Análise Econômica, 30(57), 313-337.

Tobin, J. (1958). Estimation of relationships for limited dependent variables. Econometrica, 26(1), 24-36.

Received: October 11, 2019

Accepted: December 18, 2020

JEL Classification: C34, Q50, Q56 
Appendix A. Correlation matrix between explanatory variables.

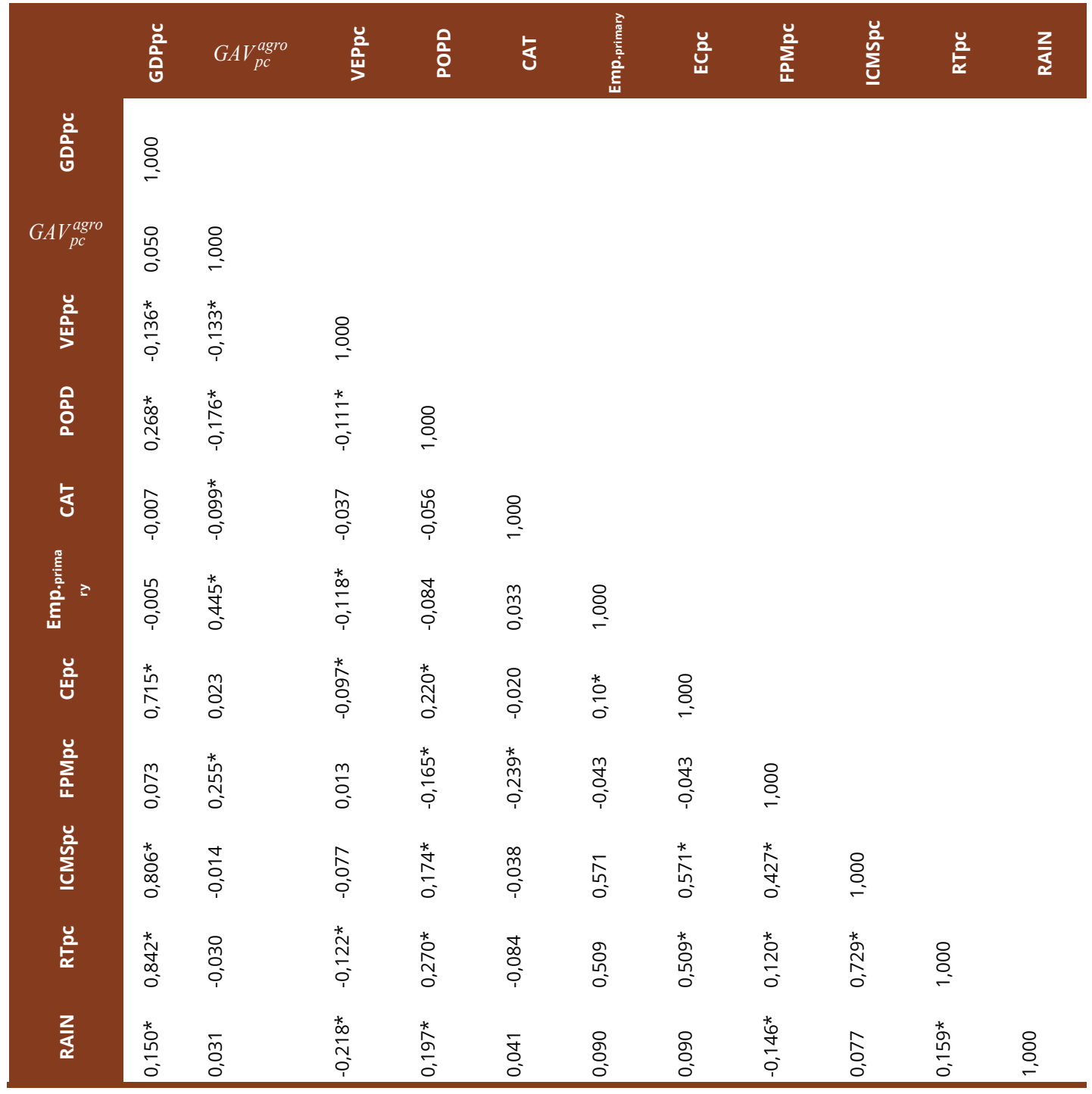

Source: Based on research data. Note: * denotes the significance at the $5 \%$ level. 